\title{
Luther and Zwingli's Eucharistic Controversy: A Reflection on Nigerian Christianity
}

\author{
Patrick E. Nmah* \\ http://dx.doi.org/10.4314/ujah.v14i2.6
}

Abstract

This study, a descriptive survey research, presents the Eucharistic ideologies of Martin Luther and Huldrych Zwingli in respect to Nigerian Christianity. The conflict between Luther and Zwingli on Eucharist began in 1525, but it was not until 1527 that Zwingli engaged directly with Luther. For Luther, Eucharist is a 'visible physical sign' of the promises of God, while Zwingli understood it to mean a 'sign of the believers' faithfulness to each other. To Luther and Zwingli, there are two sacraments (baptism and Eucharist) whereas for the Roman Catholic Church, they are seven (baptism, Eucharist, Penance, Confirmation, Marriage, Ordination, and Extreme Unction). The Catholic Church transubstantiation of elements of the Eucharist and Luther's doctrine of consubstantiation controversy are also areas of concern for this paper. The method of approach is dogmatic (especially descriptive) with the review of related literature.

\section{Introduction}

The Protestant Reformation of the sixteenth century was Luther's Reformation. Although it had its own history in many lands. Luther had two basic ideas, which have been the starting point for the Protestants or Evangelisticals everywhere. They are:

1. that the beginning of Christian faith and theology is that God has made sinners righteous through what he did in Jesus Christ, and 
2. that the only sure and dependable source for Christian faith and life is the Bible (Thomson, 1995).

The Reformation in Switzerland was begun by Zwingli, a priest in Zurich. He was trained as a humanist, and was a friend of one of the greatest humanists, Desideratius Erasmus. Although he was influenced by Luther's teaching, Zwingli can perhaps be called a "radical humanist" (Thomson, 1995). Zwingli began his career as a Reformer by preaching a series of sermons, going straight through Erasmus' Greek text of the New Testament. The two most important of Zwingli's beliefs were:

1. that the Bible is the complete guide to the Christian faith,

2. that the chief teaching of the Bible is God's direct rule over the world and human life.

According to Atkinson (1982), the differences between the Reformers received their bitterest expression in the matter of their Eucharistic theology. Zwingli rejected outright the Roman doctrine of transubstantiation and with it Luther's view of the "real presence" which he saw as a conservative compromise with the medieval position. By the sacrament, Zwingli understood quite simply a spiritual feeding of the faithful, who by partaking in faith, heard the word of God and received the Holy Spirit. To Zwingli, Christ was available everywhere by faith and did not "require" the sacrament to make that real. He was indeed a man of sober intelligence and behaved much better than Luther in controversy.

The strength of this paper is that it generates information that can enlarge the knowledge of contemporary Christians in Nigeria regarding the different Eucharistic hermeneutics in Nigerian Christianity. The aim again is to motivate and encourage Nigerian Christians to intensify their 
efforts in educating people about Eucharist and its efficacies in the lives of believers.

\section{Conceptual framework}

The title "Eucharist" denotes "thanksgiving" for the central act of Christian worship is explained either because at its institution Christ "gave thanks" or because the service is the supreme act of Christian thanksgiving. Other names are the "Holy Communion", "the Lord's Supper", and the "Mass" (Livingstone, 1980). That the Eucharist convened to the believer the Body and Blood of Christ was universally accepted from the first century. The Eucharistic elements were themselves referred to as the Body and Blood. At the fourth Lateran Council (1215) the transubstantiation of the elements was affirmed.

According to Chiegboka (2012), the Eucharist is a unifying factor among the faithful. It both signifies and brings about the unity of the church. The term has come down to us from the didache, the teaching of the Apostles which goes back to the first century AD. St. Luke in Acts of the Apostles narrates how the Eucharist brought the early Christians together and that the Christian community in Jerusalem began to break bread after receiving the Holy Spirit promised by Jesus (Acts 2:42-46). It was the Eucharist that brought them together on Sundays (Acts 20:7) where they gathered for the breaking of the bread.

The most obvious, as well as the most characteristic feature of the Eucharistic celebration at the apostolic era was its unifying aspect. When the Christians at Corinth appeared to forget this, Paul had to call them to order and in strong terms disapproved of their lack of genuine mutual love which was the key note of the Eucharist (1Cor. 11:23-27). Paul opined that the aim of gathering to celebrate the Eucharist and to share the mystery of the body and blood of Jesus Christ is to put an 
end to all kinds of divisions and factions among them. It was Paul's expectation that the Eucharist should strengthen the bond of love and brotherhood among the faithful.

The introductory words of the Eucharistic celebration taken from 2Corinthians 13:14 (The grace of the Lord Jesus Christ and the love of God and the fellowship-koinonia, communion-of the Holy Spirit be with you all) have farreaching significance. These words are supposed among other things to remind the faithful that they are one. They form a koinonia, a communion or a fellowship as a result of the action of the Holy Spirit. The word "fellowship or koinonia" has long history. Koinonia are people who are united for a common purpose, who own something in common and who share in common interest. Fellowship or koinonia denotes a way of living, being and acting characteristic of a united people (Chiegboka, 2012). To Chiegboka (2012), the sacrament of the Holy Eucharist is the true body and blood of Jesus Christ, together with his soul and divinity, under the appearance of bread and wine. Although there are several theologies of the Eucharist, it will be more appropriate to have a common Eucharistic theology.

The Council of Trent reaffirmed the doctrine of transubstantiation, but since the second Vatican Council, some Roman Catholic theologians have explored the notions of "transignification" and "transfinalization" to express the mode of the Eucharistic presence.

\section{Luther's Eucharistic ideology}

Born within weeks of Zwingli, like him Martin Luther was indebted to Erasmus for making available a printed New Testament in Greek. Luther was also a "humanist" in the sense that he encouraged education in eloquence by a study of the Greek and Latin classics (Edwards, 1998). 
Martin Luther's divisive attitude toward the Swiss branch of the Reformation, due to their diverging approaches to the Lord's Supper, is well known. Luther was a conservative reformer, retaining the sacramental emphasis of the Patristic and Medieval Church. Zwingli's humanistic tendencies led to an abandonment of several Patristic and Medieval approaches to the theology and worship including the Sacramental nature of the church. This allowed Zwingli to adopt a symbolic view of the Lord's Supper. According to Zwingli, the bread and wine simply represent Christ's body and blood.

The Lutheran Theory teaches a real and substantial presence of the very body and blood of Christ, which was born of the Virgin Mary, and suffered on the cross, in, with, and under (in, sub, cum) the elements of bread and wine, and the oral manducation of both substances by all communicants, unworthy and unbelieving, as well as worthy and believing though with opposite effects. The simultaneous co-existence or conjunction of the two substances is not a local inclusion of one substance in neither the other (impanation), nor a mixture or fusing-together of the two substances into one; nor is it permanent, but ceases with the sacramental action. It is described as a sacramental, supernatural, and incomprehensible union. The earthly elements remain unchanged and distinct in their substance and power, but they become the divinely appointed media for reflecting to heavenly substance of the body and blood of Christ. They become so, not by priestly conservation, as in the doctrine of transubstantiation, but by the power and word of God. The eating of the body is by the mouth, indeed, yet is not Capernaitic, and differs from the eating of ordinary food. The object and use of the Lord's Supper is chiefly the assurance of the forgiveness of sins, to the comfort of the believer. This is the scholastic statement of the doctrine, as given by the framers of 
the Formula Concordiae, and the Lutheran scholastics of the seventeenth century.

\section{Zwingli's Eucharistic ideology}

The Bible is central in Zwingli's work as a reformer and is crucial in the development of his theology. This is strongly evident in his early writings such as Archeteles, the Clarity, and Certainty of the Word of God (1522). The theology of Huldrych Zwingli was based on the Bible, taking scripture as the inspired word of God and placing its authority higher than human sources such as the Ecumenical Councils and the Church Fathers. He recognized also the human element within the inspiration noting the differences in the canonical gospels. He developed the symbolic view of the Eucharist. He denied the Catholic doctrine of transubstantiation and following Cornelius Henrici Hoen, he agreed that, the bread and wine of the institution signify and do not literally become the body and blood of Christ. Zwingli did not see the need for a "sacramental union" in the Lord's Supper because of his modified understanding of sacraments. The sacrament, according to him, is a sign of sacred thing, of a grace that has been given. For Zwingli, the idea that the sacraments carry any salvific efficacy on themselves is a return to Judaism's ceremonial washings that lead to the purchase of salvation.

Whereas Luther sought to prune the bad branches off the tree of Roman Catholic sacramentalism, Zwingli believed the problem to be rooted at least partly in sacramentalism itself. The only way to legitimately resolve Roman excess was to reinterpret the nature of the sacraments. Pruning the tree was not enough; pulling the tree up from its roots was the only action that could actually fix the problems. Zwingli initially appealed to scripture against Catholic opponents in order to counter their appeal to the church which included the councils, 
the church fathers, the schoolmen, and the popes. According to him, these authorities were based on man and liable to error (Stephens, 1986). He noted that "the fathers must yield to the word of God and not the word of God to the fathers. His insistence of using the word of God did not prelude him from using the Councils or the Church Fathers in his arguments. The inspiration of scripture, the concept that God or the Holy Spirit is the author, was taken for granted by Zwingli (Stephens, 1986).

At this point, we can understand Zwingli's position visà-vis Luther's if we consider the background and development of Zwingli's view on the sacrament, and the Eucharist in particular. As Luther drew attention to the idea of the sacraments as "signs" of the promises of God, Zwingli understood "sacrament" to denote the idea of an "oath" or "pledge". He saw baptism and the Eucharist, much like Luther, as tokens of God's faithfulness to his people and as signs of his divine redemptive promises. By 1525 Zwingli changed his position by seeing the sacraments not as the "signs" of God's faithfulness to believers; the sacraments came to be "signs" of the believers' faithfulness to each other. It was no longer a divine pledge to humans, but a human pledge to other humans within the context of the community of the Christ faith.

Zwingli's view on the Eucharist (as well as baptism) is heavily influenced by two factors namely as Chaplain in Swiss military Confederacy and his interpretation of Matthew 26:26. If Luther's doctrine is correct, then either scripture is incorrect (which Luther would naturally not deny) or Christ is in two places at the same time(and presumably in the same respect). Since the scripture is true and the latter involves a contradiction, Luther's thesis must be false. Luther's response was not amazing. The phrase, "at the right hand of God", Luther said should not be taken literally. It is metaphorical for God's rule or sphere of influence. Christ is nowhere literally, 
as he is not confirmed by temporal or spatial location. Again, biblical interpretation was basic in the debate, one may say that the bread and wine possess no inherent spiritual meaning, but the religious significance of the elements is determined by those elements being placed within the community of the Christian faith. For Zwingli, sacraments presuppose the possession of faith. They represent the believer's active and deliberate move to give allegiance to the Christian community. Infants obviously are not capable of this conscious and deliberate action. Since the time of Augustine, theologians have, traditionally, argued that baptism cleansed the guilt of original sin. Like Erasmus, Zwingli had problems coming to grips with the doctrine of original sin; he therefore tended to think that infants did not have any inherent original sin. As a result, they had no need to be forgiven.

Zwingli's theory on the Lord's Supper is a solemn commemoration of the atoning death of Christ, according to his own command: "Do this in remembrance of me" and the words of Paul: "As often as ye eat this bread and drink the cup, ye proclaim the Lord's death till he come." Zwingli emphasized his primitive character of the institution as a gift of God to man, in opposition to the Roman Mass as a work or offering which man makes to God. He compares the sacrament to a wedding ring which seals the marriage union between Christ and the believer. He derived the corporal presence, because Christ ascended to heaven, and because a body cannot be present in more than one place at once. Also because two substances cannot occupy the same space at the same time; but he admitted his spiritual presence, for Christ is eternal God, and his death is forever fruitful and efficacious. He denied the corporal eating as Capernaitic and useless, but he admitted a spiritual participation in the crucified body and blood by faith. Christ is both "host and feast" in the Holy Communion. 
His last word on the subject of the Eucharist (in the confession to King Francis I) is this: "we believe that Christ is truly present in the Lord's Supper; yea, that there is no communion without such presence. We believe that the true body of Christ is eaten in the communion, not in a gross and carnal manner, but in a sacramental and spiritual manner by the religious believing and pious heart."

\section{Luther and Zwingli's Eucharistic ideological conflict}

For Zwingli it was a matter of attacking a doctrine that imperiled the understanding and reception of God's gift of salvation, while for Luther it was a matter of defending a doctrine that embodied that gift. Zwingli credited the Dutch humanist, Corndlus Henrici Hoen (Honius), for first suggesting the "is" in the institution words, "This is my body" meant "signifies" (Potter, 1976). Zwingli denies transubstantiation using John 6:63, "It is the Spirit who gives life, the flesh is of no avail" as support. In the Eucharist (1525), following the introduction of his communion liturgy, he laid out the details of his theology where he argues against the view that the bread and wine become the body and blood of Christ and that they are eaten bodily (Stephens, 1986).

The conflict between Zwingli and Luther began in 1525 , but it was not until 1527 that Zwingli engaged directly with Luther. The culmination of the controversy was the Marburg Colloquy in 1529. He wrote four response leading up to the meeting: A Friendly Exegesis (1527), A Friendly Answer (1527) Zwingli's Christian Reply (1527), and Two Replies to Luther's Book (1528) (Courvoisier, 1963). They examined Luther's point of view rather than systematically presenting Zwingli's own.

A dispute over indulgences (papal certificates guaranteeing absolution) soon became a question of the very nature of the church. Led by Martin Luther, the Reformers 
challenged the whole fabric of medieval Catholicism in the name of the gospel of salvation by grace alone (Milne, 1993). The Reformation did not produce one common view, but a single approach covering several relatively diverse interpretations. Luther rejected the Roman claims for the infallibility of the church under the leadership of the Pope, the sacerdotal priesthood and the automatic operation of the sacraments (the claim that they automatically convey grace, regardless of the faith, or lack of it, of the recipient).

Eucharist in the Catholic church refers to both the celebration of the mass that is, the Eucharist liturgy, and the bread and wine which after the consecration are transubstantiated (changed in substance) into body and blood of Jesus Christ, Lord and God. Blessed Sacrament is a devotional term used in the Roman Catholic Church to refer to the Eucharistic species (the Body and Blood of Christ). The Catholic Church sees as the main basis for this belief the words of Jesus himself at his last supper: the Synoptic Gospels (Matthew 26-28, Mark 14:22-24; Luke 22:19-20) and Saint Paul's Corinthians 11:23-25(cf. 1Corinthians 10:16, 11:27).

\section{Luther and Zwingli's Eucharistic controversy: a reflection on Nigerian Christianity}

Holy Communion or the Lord's Supper is considered of great spiritual significance to the communicant in Cherubim and Seraphim (Omoyajowo, 1982). The Elder who will celebrate it has to announce in advance that, "Those who are conscious of their sins or who have quarrel with their neighbours should now repent and settle with them before venturing to come to the Communion Service." This service is also taken from the Anglican Book of Common Prayer. The Ante-Communion and the prayer of humble access are omitted. It is believed that the sacrament consists of the breaking of bread which represents 
his body broken for us and the drinking of wine which represents his blood shed for us on the cross on Calvary. It should be taken only by truly converted believers in Christ, reverently and with penitence for their spiritual sustenance. "It is a great offense before God to take it unworthy" (1Corinthians 10).

Interestingly enough, there is a Confirmation Service in the Cherubim and Seraphim (C \& S) liturgy despite the absence of infant baptism. The service is for people above the age of sixteen who must:

1. possess a praying gown of their own;

2. know the rules and regulations of the Holy Order;

3. know who Cherubim and Seraphim are;

4. know the meaning of white praying gown, visions, dreams, clapping, stamping the ground, dancing during service, shouting "Halleluiah", consecration of water and oil for healing, burning of incense, use of candles, necessity for fasting and constant prayer;

5. know the works of the flesh and the fruits of the Spirit;

6. know the Lord's prayer and the creed(Omoyajowo, 1982).

The candidates are marshaled in the chancel, and the officiating Apostle pronounces that in view of their promise "to renounce the devil and all his works and to be steadfast in the faith of the society, 'it is expedient' for them to receive the gift of the Holy Ghost that they may be able to fulfill their promises and vows." After the candidates have expressed their willingness to receive the Holy Ghost, the Apostle prays for them and lays his hands upon them.

Holy Communion in Cherubim and Seraphim is, however, connotes eating the flesh of Christ and drinking his blood spiritually as they dwell in Christ and Christ in them. In Deeper Life Bible Church of Nigeria, the Eucharist is celebrated once, depending on the date or season of the year 
they decide to have it. Like any other Pentecostals, it is done in remembrance of Jesus' death with unleavened bread and juice from grape vine. The scarcity of these elements tells more why they celebrate the Eucharist once in a year. For the Living Faith Church, the elements represent the blood and body of Jesus, which according to the Church, is acceptable to God for the forgiveness of sins and which also scare away the devil (Oyedepo, 1985). For the Redeemed Christian Church of God, the elements of Eucharist denote eating the body and blood of Jesus Christ without which one will not have life in oneself (John 6:53). Those who partake in the Eucharist missed death and are favoured among other benefits.

To Keeley (1982), the Roman Catholic doctrine of transubstantiation officially stated in AD 1215 at the Fourth Lateran Council affirmed and expounded more fully during the sixteenth-century council at Trent, and recently reaffirmed in the encyclical Mysterium Fidei in 1965 following the Second Vatican Council. It states that, when the priest pronounces the words of Christ, "This is my body" and "This is my blood; the elements of bread and wine are miraculously changed into the body and blood of Jesus. These are then offered to God as for sins of the living and the dead: the congregation worships them as the priest lifts them up; and when the congregation partakes of the bread (not the wine), they really receive Jesus Christ's body and blood.

Like other Christian churches, Pentecostals believe that certain rituals or ceremonies in the New Testament were instituted as a pattern and command by Jesus in the New Testament. Pentecostals commonly call these ceremonies ordinances (Livingstone, 2000). Many Christians call them sacraments, but this is not generally used by Pentecostals as they do not see ordinances as imparting grace. Instead the term sacerdotal ordinance is used to denote the distinctive belief that 
grace is received directly from God by the congregant with the officiant serving only to facilitate rather than acting as a conduit or vicar.

The ordinance of baptism is an outward symbol of an inner conversion that had already taken place. Therefore, most Pentecostal groups practice believer's baptism by immersion. The majority of Pentecostals do not view baptism as essential for salvation, and likewise, most Pentecostals are Trinitarian and use the traditional Trinitarian baptism formula (Duffied and Van Cleave, 1983).

The ordinance of Holy Communion, or the Lord's Supper, is seen as a direct command given by Jesus at the Last Supper, to be done in remembrance of him. Pentecostal denominations reject the use of wine as part of communion, using grape juice instead. Foot washing is also held as an ordinance by some Pentecostals. It is considered as an "ordinance of humility," because Jesus showed humility when washing his disciple's feet in John 13:14-17. Other Pentecostals who do not consider it as ordinance may still recognize spiritual value in the practice (Assemblies of God, 1985).

Pentecostal churches practice "open" or "inclusive" communion that is where every adult Christian partakes in the Lord's Supper irrespective of denomination. The terms "open" (or "inclusive") or "closed" (exclusive") communion came from debates about some rather archaic practices that deny communion to people who are not specifically members of one particular denomination. The reason for "closed" communion (the denial of communion to "outsiders") is to prevent anyone from taking it that does not understand its meaning and does not agree with the doctrine of the church (thus, in some ways protecting the pastor's or pastoral's conscience). Pentecostal churches have as "open" table, meaning anyone can participate at the Lord's Supper when communion is offered. 
Unlike some liberal denominations, the reason for the "open" table is more than being "inclusive" or "accepting" of others, but rather, it is because the responsibility for one's salvation is ultimately up to the individual, and therefore Pentecostal churches will offer communion to everyone, but will explain in detail what it means to participate so that no one takes communion in a manner that will cause condemnation upon oneself. Pentecostal Christians do not believe that the elements used (bread and wine grape juice) mystically transform, as for example, the Catholic Church teaches.

The practise of the Lord's Supper was instituted by Jesus, the Saviour of the world. His disciples participate in the ordnance out of reverent obedience to the Lord, and in "remembrance" of him, as the scriptures instruct:

That the Lord Jesus on the night when he was betrayed took bread, and when he had given thanks, he broke it, and said, "This is my body which is for you. Do this in remembrance of me." In the same way also the cup, after supper, saying, "This cup is the new covenant in my blood. Do this, as often as you drink it, in remembrance of me". "For as often as you eat this bread and drink the cup, you proclaim the Lord's death until he comes (1 Cor.11:23b-26).

What the scripture says here influences exactly what biblical churches do as they strictly adhere to practising biblical repentance prior to receiving the Lord's Supper. 1Corinthians 11:27-32 instructs that each must examine himself and properly discerned his body. The Pentecostal church does not share the beliefs regarding communion of the Catholic or Orthodox Church. Therefore, all parishioners are welcome. Most Pentecostal churches will simply pass out the 
bread and wine/grape juice through the pews. It is based on the idea that Jesus is the "Soon coming King" (Poloma, 1989). The Catholic Church is of the idea that there is no Eucharist because there are no valid sacraments. It is only bread and grape juice which in other words is just symbolic to them. Communion for the Pentecostals connotes, however, the sharing of a common spirituality among a group of believers.

\section{Conclusion and recommendations}

Despite the great deal of unanimity within the magisterial Reformation, the various reformers not only gave emphasis to different doctrines (for instance, Luther's "Justification by faith" and Zwingli's "the sovereignty of God"), but some reformers displayed a substantial disagreement over particular doctrines. Perhaps the most significant of these doctrinal disagreements, certainly the most perspicuous, is the debate between Martin Luther and Huldrych Zwingli over the nature of the sacraments of baptism and the Eucharist (or Lord's Supper).

Although Luther originally maintained that there were three sacraments (baptism, Eucharist and penance), but sometimes during his Babylonian captivity of the church (1520) he reduced the sacraments to just two having eliminated penance. The restriction of these sacraments to baptism and Eucharist begins late in the cited 1520 text. Towards the end of this work, Luther begins to emphasize the notion of a "visible physical sign" of the promises of God. This then becomes the criterion for selecting baptism and the Eucharist as sacraments, for "only in these two do we find the divinely instituted sign and the promise of the forgiveness of sins." So, whereas the Roman Catholic Church had recognized seven sacraments (Baptism, Eucharist, Penance, Confirmation, Marriage, Ordination and Extreme unction), Luther came to believe that there were in fact only two sacraments. 
Sacrament is not a demonstration of faith possessed (as Zwingli maintained), but a mode of generating faith. This is crucial, since it allows Luther to accept both the doctrine of justification by faith and infant baptism. If justification by faith were conceived as involving a human work, decision, or a human response to the divine promises, then justification by faith would be incongruous with infant baptism. The faith by which we are justified is God's gracious gift to the individual and it comes by the hearing of the gospel promises. Since the sacraments mediate the word of God, and "his word cannot be without fruit, "baptism can be seen as generating, rather than presupposing faith,

The doctrine was based upon the Aristotelian distinction between substance and accident. The former is a thing's essential nature, whereas the latter is a thing's inessential properties (or outward appearances). Some have maintained that Luther's position consisted in the rejection of the "real presence" of Christ in the Eucharist. He is said to have held that Christ presence was not in the elements, but merely behind them. Hence, a doctrine of consubstantiation replaces one of the transubstantiation. Luther taught the real presence of Christ can be seen in his urging, with much vehemence, the text of Matt 26:26: hoc est corpus meum -"this is my body." Over against Zwingli, Luther argued that "est" must be understood to mean "is identical with." Consequently, "This is my body" must be interpreted literally. This bread is identical with my body.

Transubstantiation (from Latin transsubstantiatio) is the change of the substance of bread and wine into that of the body and blood of Christ, the change that according to the belief of the Catholic Church occurs in the Eucharist. It concerns what is changed (the substance of the bread and wine), not how the 
change is brought about. "Substance" here means what something is in itself.

For the Pentecostal Churches in Nigeria, they do not partake of communion to receive forgiveness of sins. There is no power in the sacrament to give the recipient forgiveness (Douglas, 1985). They partake in Communion in obedience to the command of Christ (1Cor11:24). It is celebrated in anticipation of his soon return (1Cor 11:26). At the communion Jesus would draw near to commune with us as on the Emmaus road. Those who have right to sit at Jesus' table in fellowship with the Lord are those born into the family of God.

For Deeper Life Bible Ministry, the bread seen symbolically as the Lord's broken body and blood that was shed. To the Living Faith (a. k. a Winners Chapel), the bread is the flesh of Jesus Christ, and the blood is the blood of Christ that when one partakes of it one experiences spiritual blood transfusion (Oyedepo, 2011).

It is imperative to note that most of the independent churches in Nigeria do not attach so much importance to the meaning of the Eucharistic elements. Many of them simply infer that the bread and wine (grape juice) are the body and blood of Jesus Christ, which in other words denotes Christ death on the cross. The research discovered also that many of the priests and members of the mainline churches alongside the new religious movements do not understand the meaning of these Eucharistic elements, probably, because they were not adequately taught that during their formation institutions and in their churches.

At this juncture, it is imperative to recommend that there should be a comity of the churches in Nigeria to share ideas with respect to the meaning of the Eucharistic elements. The Pentecostal churches in Nigeria should evolve conference to deliberate on the meaning of Holy Communion elements so as to have definite meaning of the elements. They should 
come up with a common definition of the Eucharist. The elements of the Eucharist should not be handled by any laity except those ordained priests. The formation centers or theological colleges should devote much time to teach the new generation priests the efficacy and the real meaning of the Eucharistic elements in the lives of believers.

Moreover, the Bible, the fathers of the church, the liturgy and Christian theology make it abundantly clear that the Eucharist is a major unifying factor in the church. Through the Eucharist the risen Christ builds, nurtures and cements the unity that exists between him and his members and among the members themselves. That is why the words of 1Corinthians 10:17 states that "because there is one bread, we who are many are one body, for we all partake of the one bread," is repeated often in the Eucharistic celebration.

In conclusion, the debate between Luther and Zwingli on the sacraments and as it affects Nigerian Christianity establishes a more general point about the reformation itself and its theology. Although the reformers sought to emphasize the perspicuity of the Scriptures, it must be admitted in the light of inter-reformation controversies that the Scripture was not as clear as the reformers' doctrine of perspicuity might have suggested. Different interpretations of Scripture played a substantial role in the debates between Luther and Zwingli. But these different interpretations serve to show that there can be no adequate appeal to Scripture without also considering principles of interpretation and an interpretative tradition. And this, I suggest, is to commit ourselves to employing the powers of reason in theology. Therefore, if the reformation principle of sola scriptura is to be a coherent principle, it cannot be understood as many Reformed writers (especially in the 20th century) have understood it-as excluding an appeal to reason unaided by revelation. The appeal to Scripture presupposes a 
fundamental commitment to reason, and perhaps in the union of revelation and reason which is required in the Reformed tradition, even if it has been a tacit assumption not explicitly articulated, we can see a more general continuity between the theology of the Medieval and that of the reformers.

Patrick E. Nma is of the Department of Religion and Human Relations, Nnamdi Azikiwe University, Awka.

\section{References}

Atkinson, J. (1982). Martin Luther and the birth of Protestantism. London: Marshall Morgan \& Scott.

Chiegboka, A. B. C. (Ed.) (2012). Trends in religion \& society/Christian ethics: selected essay of Very Rev Msgr Prof J. P. C. Nzomiwu. Awka: Fab Anieh.

Courvoisier, J. (1963). Zwingli, a reformed theologian. Virginia: John Knox.

Douglas, A. (1985). God's answer to man's questions: 100 Bible lessons. Greenville:-

Duffield, G.P. and Van Cleave, N.M. (1983). Foundations of Pentecostal theology. Los Angeles: Foursquare Media.

Edwards, D.L. (1998). Christianity: the first two thousand years. London Cassell.

General Council of the Assemblies of God (1985). Abstinence: A biblical perspective on Abstinence. MO: Springfield. Keeley, R. etal (Eds.). (1982). The Lion Handbook of Christian belief. Hertz: Lion.

Livingstone, E. A. (Eds.). (1980). The concise oxford dictionary of the Christian Church. Oxford: Oxford University Press.

Livingstone, E. A. (2000). Pentecostalism. The Oxford dictionary of the Christian Church. London: Hodder and Stoughton. 
Milne, B. (1993). Know the truth: a handbook of Christian belief. Leicester: Inter-Varsity Press.

Omoyajowo, J. A. (1982). Cherubim and Seraphim: The history of an African independent church. Lagos: NOK.

Oyedepo, O. (1985). The blood triumphs. Lagos: Dominion.

Oyedepo, F. O. (2011). The power of the communion table. Lagos: Dominion.

Poloma, M. M. (1989). The Assemblies of God at the crossroads: Charisma and institutional dilemmas. Knoxville, Tennessee: Tennessee University Press.

Potter, G.R. (1976). Zwingli. Cambridge: Cambridge University Press.

Stephens, W.P. (1986). The theology of Huldrych Zwingli. Oxford: Clarendon.

Thomson, A. (1995). New Movements: Reform-RationalismRevolution. London: SPCK. 